\title{
The Effect Requirements Selling In The Marketplace For Security Against Buyer Trust
}

\author{
Euis Sitinur Aisyah ${ }^{1}$, Eka Purnama Harahap ${ }^{2}$, Nabilah Salsabila ${ }^{3}$ \\ $1,2,3$ University of Raharja, Jl. Jenderal Sudirman No.40 Modern Cikokol Tangerang \\ e-mail: euis@raharia.info, ekapurnamaharahap@raharia.info, nabilah.salsabila@raharia.info
}

Author Notification 23 September 2019

Final Revised

17 December 2019

Published

27 December 2019

To cite this document:

Aisyah, E., Harahap, E., \& Salsabila, N. (2019). The Effect Requirements Selling In The Marketplace For Security Against Buyer Trust. Aptisi Transactions On Management (ATM), 4(1), 67-75.

DOI:

https://doi.org/10.33050/atm.v4i1.1093

\begin{abstract}
Marketplace is a website or online application that facilitates the buying and selling of various stores. Marketplace is of interest to sellers as well as buyers of places to transact. But fraud is one of the annoying things in a Marketplace. It is evident that for a security Marketplace as well as trust for shoppers is a top priority Marketplace. So how the requirements on Marketplace for sellers can sell on Marketplace. Does it affect fraud prevention to make the Marketplace a Marketplace of interest in Indonesia. Using the results of Marketplace statistical research studies from the biggest Marketplace position in Indonesia. View the requirements applied by the largest marketplace to see how the requirements are affected. Results show that the requirements for becoming a seller on Marketplace have a significant impact on the security and buyer confidence. It is seen that with the authenticity of the seller data, the buyer will better trust the marketplace to reduce fraud. Because if the seller cheats the buyer it will affect the good image and trust of the buyer. That way the marketplace will suffer losses. It is hoped that only the Marketplace is huge but the growing small Marketplace has increased the requirements for sellers to avoid fake identities for sellers who want to cheat.
\end{abstract}

Keywords: Marketplace, Security, Sellers

\section{Introduction}

One of these companies can provide Marketplace. Marketplace is a provider of online mall services that sell is the members who register to sell on the website of the marketplace is not the selling website providers. With online trading like this, facilitate the consumers in shopping, because all is done computerized. That is, consumers no longer come to an outlet to select and perform payment transactions. Only through smartphone or PC technology, consumers can relax at home while shopping [1].

Ease, is one of the reasons why technological developments can be accepted by the community. Everything seems to be done anywhere and anytime with the presence of this technology [5]. Currently, there are many existing marketplace in Indonesia, and doing business now depends on the marketplace for both sellers and buyers. The number of users who use the marketplace raises, requiring it to improve the quality and facilities in the marketplace in question. It is so influential in value for marketplace users. One of the security is in the marketplace, because sales and buyers use the Internet as one of the access to use the marketplace. Interference of other parties who want to harm the marketplace by earning one's advantage by cheating. Cheats on Marketplace includes a fake identity as an online seller in the absence of goods to be sold. It is also one of the causes of lack of trust and also security for buyers to the assessment of the development of information technology progressively until the business has had a huge impact on the development of technology now. It creates online buying and selling of one of them is the Marketplace. Marketplace can be considered as a provider of online mall services, 
but who sell not a website provider, but rather members who register to sell on the website of the marketplace.

Currently, there are many existing marketplace in Indonesia, and doing business now depends on the marketplace for both sellers and buyers. The number of users who use the marketplace raises, requiring it to improve the quality and facilities in the marketplace in question. It is so influential in value for marketplace users. One of the security is in the marketplace, because sales and buyers use the Internet as one of the access to use the marketplace. This modern-day payment system has been widely applied to the online business world. This online payment system called E-Payment, E-Payment commonly used in ecommerce business is also commonly used in the payment activities in different places with distant distance [4]. Interference of other parties who want to harm the marketplace by earning one's advantage by cheating. Cheats on Marketplace includes a fake identity as an online seller in the absence of goods to be sold. It is also one of the causes of lack of trust and also security for buyers to the Marketplace's assessment. More and more scams are getting more and more disappointed and unwilling to use the Marketplace.

Based on the problems that occur above, this research is done to let users know that the seller's terms affect the authenticity of seller's identity in the marketplace. The better the security in the marketplace for requirements as a seller in the marketplace. The better it will be to reduce the fraud.

Age:
53 tanggapan

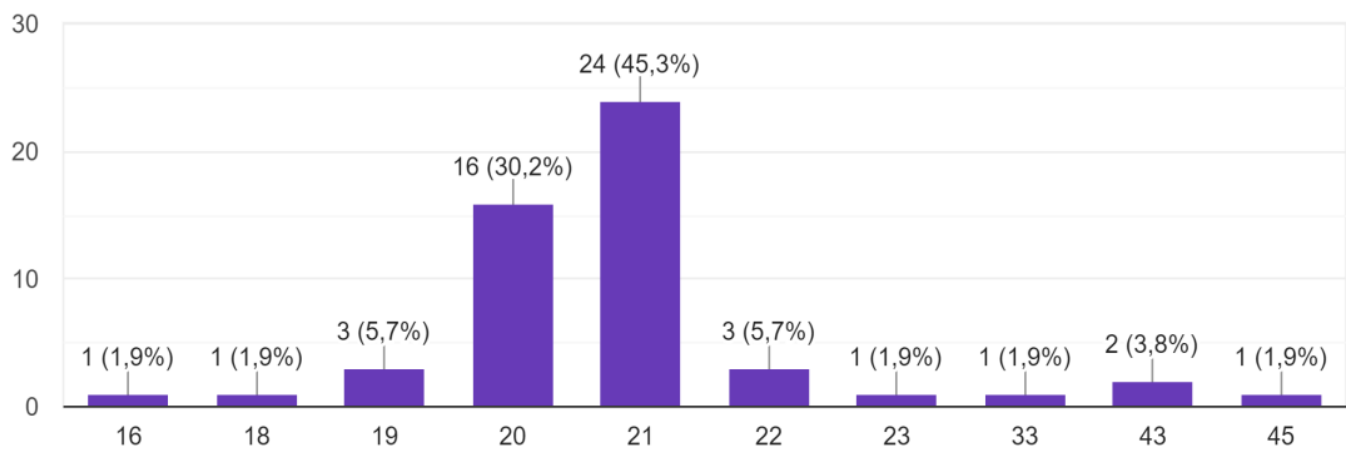

Figure 1. Sample Age

Get a sample with a age of 21 majority with a Total of 24 people followed by the age of 20 with a Total of 16 people passed on age 19 and 22 with 3 people and up to $26-45$ years of age from 53 response questionnaires. 
Gender :

53 tanggapan

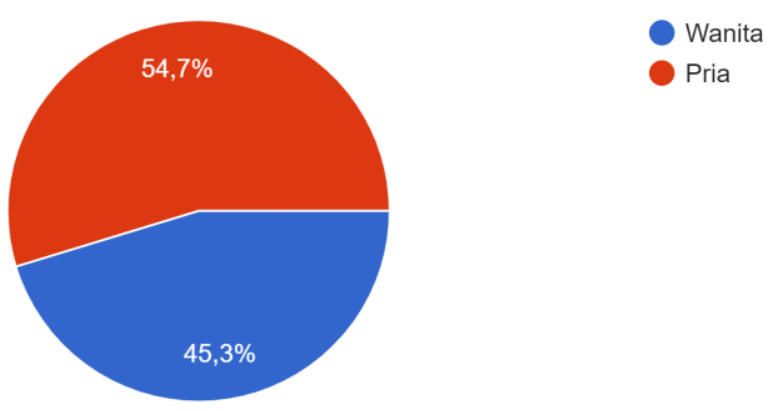

Figure 2. Sample Gender

Out of 53 responses of $54.7 \%$ were 29 men's gender and $42.5 \%$ were 24 female genders.

What Ever Shopping in The Marketplace??

53 tanggapan

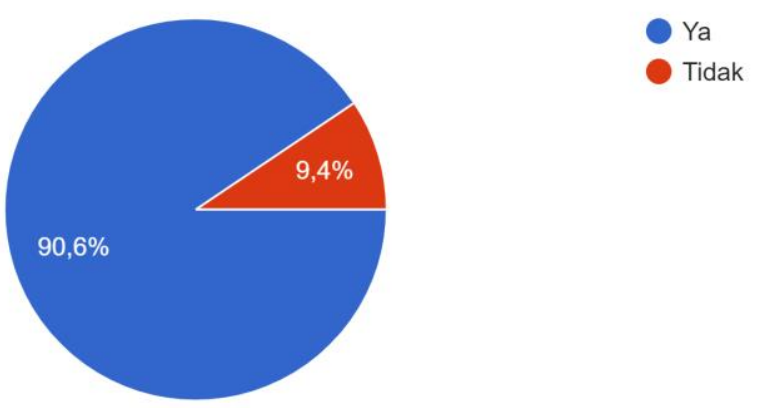

Figure 3. Sample Shopping on Marketplace

$90,6 \%$ with 48 people have been shopping on Marketplace and $9.6 \%$ with 5 people have never shopped in a Marketplace. 
Where is the Marketplace you've ever been?

48 tanggapan

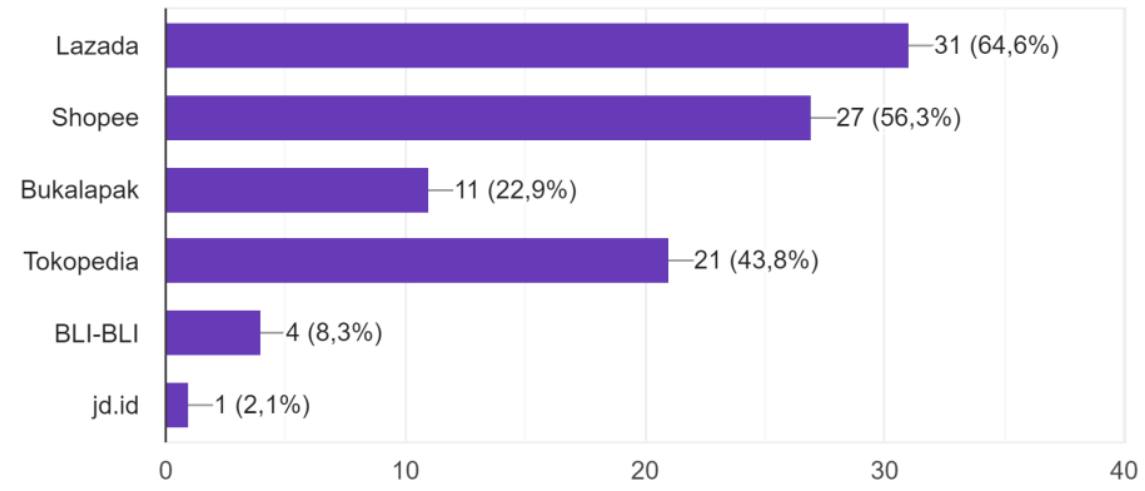

Figure 4. Sample Place Marketplace

Lazada became the first Marketplace with $64,6 \%$ of 31 people last response to Shopee with $56,3 \%$ of 27 people followed by Tokopedia $43.8 \%$ of 21 people responded then Bukalapak $22.9 \%$ of 11 people then at the incessant bli-bli $8.3 \%$ of 4 People and JDid 2.1 of 1 person total of all 48 total people who responded.

\section{Have You Ever Been Tricked}

48 tanggapan

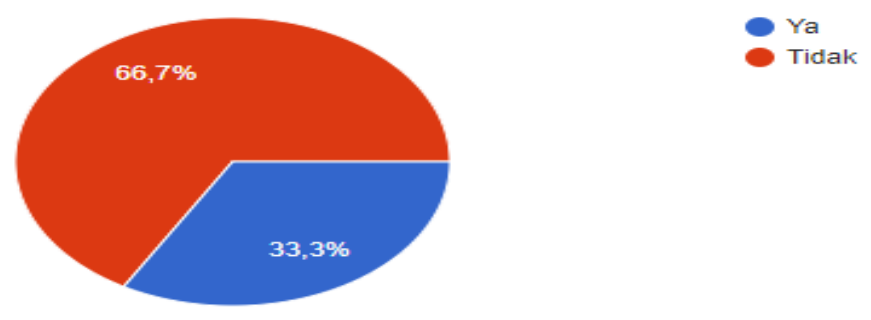

Figure 5. Sample Tricked

From 53 people, $66.7 \%$ of the response was 32 people said it was never deceived and $33.3 \%$ were 16 people responding yes already been deceived by the seller. 


\section{Where Do You Shop For a Tricked?}

16 tanggapan

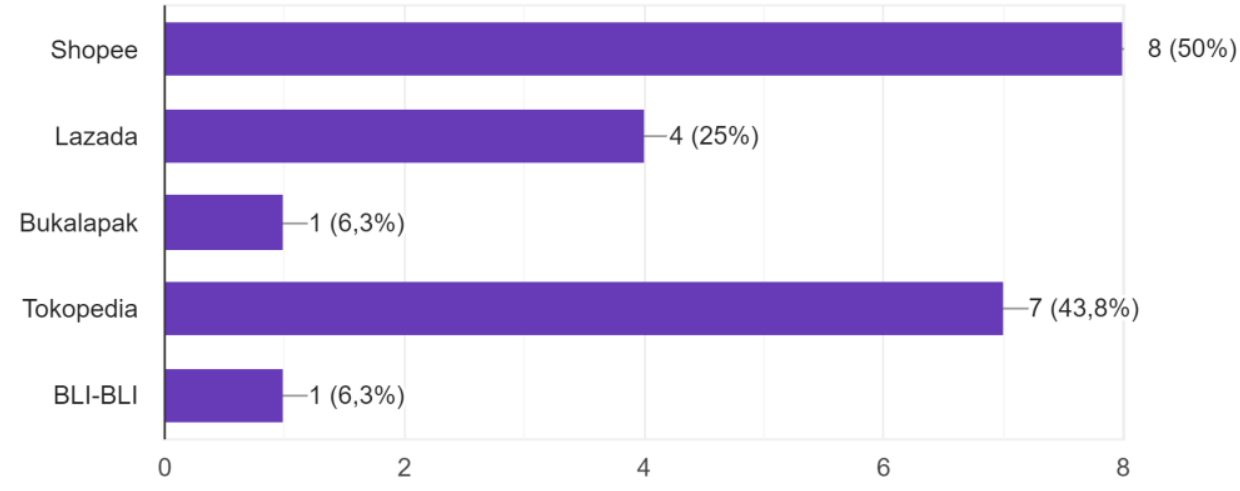

Figure 6. Sample Tricked

Shope became the first $50 \%$ order of the 8 people who had been deceived in a Marketplace followed Tokopedia $43 \%$ of 7 people followed by Lazada, Bukalapak and OLX.

\section{Research Method}

Research needs to be conducted by the study of the library as one of the implementation of research methods to be conducted. Among them is to identify the largest marketplace in Indonesia, identifying Indonesia e-commerce law, knowing other people specializing and the same area of research in this field. Some of the literature reviews are as follows:

According to the research of customers ' customer satisfaction over the performance of Rooster Services in the College of research data derived from the dissemination of online questionnaire (iSur) to 20 respondents who had been made a ticket in Rooster. From an online questionnaire (iSur) It was concluded that the Rooster service has an effect on customer satisfaction. While customer satisfaction and trust are factors that influence the customer's intention to re-use Rooster. The findings of this research show that overall customer satisfaction has a strong influence to re-use Rooster [2].

This research was conducted by Ahmad Farki, Imam Baihaqi, and Berto Mulia Wibawa (2016) entitled "The Influence of Online Customer Review and Rating on the trust and interest in purchasing on Online Marketplace in Indonesia". This study learned by knowing the impact of OCR on online marketplace in Indonesia by adding a new variable that is rating. The method used in this research is the Structural Equation Modelling (SEM) method with 313 respondents the results gathered from Internet users who have been shopping online in the marketplace. Generating both review and rating OCR has been proven to have a relationship to interest in customer purchases and is also one of the most important features, but not a factor that leads to increased customer confidence. As a result online companies that are marketplace should make reviews and ratings as one of the main marketing tools that can increase the company's revenue [7].

Research conducted by urged Made Prilia Damayanti (2016) titled "A Study of criminal acts fraud through trading". This research describes the necessary criminalization policy and in the criminal act of online trading fraud is governed by article 378 of the criminal CODE of fraud. The form of legal protection against victims of fraudulent online trading fraud, which is the granting of rights and obligations of victims and the provision of restitution and compensation [8].

The effect of security, simplicity, trust, and performance risk of Online purchase decisions Tokopedia.com case studies in Lumajang District data collection methods with questionnaires distributed Online using Google forms. Data analysis uses descriptive analysis and multiple regression analyses. The results of the study show variable security, ease, trust and performance risk as a partial has a significant positive influence on online purchasing decisions. While the security of simultaneous variables, easy, trust, and performance risks has a significant positive effect on online purchasing decisions. While the most dominant in influencing online purchasing decisions is security [9]. 
Impact management on customer relationship factors in seeing the level of satisfaction and loyalty in Marketplace customers in Indonesia in Indonesia, PT Tokopedia Indonesia is one of the online business that implements Customer Relationship Management In maintaining relationships with their customers. The company has an online buying and selling website which is an example of the market in Indonesia. This research is conducted using a descriptive method that begins with conducting surveys or interviews to find the necessary data, such as Tokopedia customer satisfaction rate data on the services provided and the level of data Often customers make transactions. The data will be analyzed to see the customer loyalty level on the Tokopedia website [10].

Analysis of E-Commerce systems in the Shopee Indonesia Mobile Marketplace company Shopee Indonesia is able to become the largest online shopping company in the first place in 2017 in Indonesia with various services and security excellence Transaction security. However, Shopee also still has a number of weaknesses, among which it seems complicated and inefficient because the presence of buyers and sellers featuring product descriptions is considered less appealing to buyers with many fraudulent consumers. Shopee Indonesia's company uses Shopee warranty strategy, free shipping, and the lowest price guarantee to make the largest online shopping company and number one in Indonesia [11].

But at some universities identified 2 (two) problems, namely the distribution of bills are done conventionally so that the information received is inaccurate and real time and students make payments by changing the receipt Payment with a receipt. In preventing both problems it takes a cloud accounting to spread the bills and make payments can be done online.

Jurnal.id is one of the cloud accounting which has the journal Payment feature that allows the cashier can easily send bills by E-mail and students settle bills online. It is hoped that the payment journal can facilitate the transaction process to produce accurate and real time data. So that it can facilitate the two parties are the cashier in the process of spreading the bill and input receive payment because it is synchronized automatically and the student in settling the bill payment online and financial Become more cashless, effective and efficient [6].

An alternative solution to the problem is to apply the APTISI official site to show the performance of the association's activities. 5 (five) literature reviews on Industrial Technology 4.0, Business Intelligence and Dashboard were conducted to determine the level of APTISI's activities in the current disruption era. In designing the system, there are 3 (three) benefits found from a problem formula using the SWOT analysis method. From what has been explained above, the APTISI official site 4.0 industry technologies can disseminate information and improve the performance of APTISI members in the dissemination of information and activities by conducting a validity and reliability test for 100 (one hundred) respondents [12].

\begin{tabular}{llllll}
\hline MARKET & RATING & RATING & DOWNLOAD & RAKING & RAKING \\
PLACE & PLAYSTORE & APPSTORE & PLAYSTORE & PLAYSTORE & APPSTORE \\
\hline LAZADA & 4,4 & 5 & 100 JUTA + & 3 & 3 \\
SHOPEE & 4,2 & 4 & 50 JUTA + & 1 & 1 \\
$\begin{array}{l}\text { TOKOPEDI } \\
\text { A }\end{array}$ & 4,4 & 5 & 10 JUTA + & 2 & 2 \\
$\begin{array}{l}\text { BUKALAPA } \\
\text { K }\end{array}$ & 4,5 & 3 & 10 JUTA + & 4 & 4 \\
BLI-BLI & 4,3 & 5 & 10 JUTA + & 9 & 10 \\
\hline
\end{tabular}

\begin{tabular}{|l|l|l|}
\hline MARKETPLACE & SELLER'S TERMS & VIOLATION POLICY \\
\hline LAZADA & $\begin{array}{l}\text { Online registration } \\
\text { and account } \\
\text { activation } \\
\text { Upload the required } \\
\text { documents (ID } \\
\text { CARD and page } \\
\text { savings book) } \\
\text { Upload products to } \\
\text { sell }\end{array}$ & $\begin{array}{l}1 \text { million per Order + Seller deactivated (Non } \\
\text { Active temporary or permanently until the } \\
\text { results of further investigation) }\end{array}$ \\
\hline
\end{tabular}




\begin{tabular}{|c|c|c|}
\hline SHOPEE & $\begin{array}{l}\text { - The products sold } \\
\text { are not listed in the } \\
\text { list of products } \\
\text { Prohibited } \\
\text { - Online registration } \\
\text { and account } \\
\text { activation } \\
\text { - Upload products to } \\
\text { sell } \\
\text { - Account to make the } \\
\text { payment or receipt } \\
\text { of money selling in } \\
\text { Shopee }\end{array}$ & $\begin{array}{l}\text { - Deletion list } \\
\text { - The limitations imposed on the } \\
\text { account hack } \\
\text { - Suspension and termination of } \\
\text { accounts } \\
\text { - Criminal charges } \\
\text { Civil actions, including by not limited } \\
\text { to claims for losses and/or damages } \\
\text { or provisional orders for damages by } \\
\text { the Court. }\end{array}$ \\
\hline TOKOPEDIA & $\begin{array}{ll}\text { - } & \text { Register as a Seller } \\
\text { - } & \text { Upload Products } \\
\text { - } & \text { Promote Your } \\
& \text { Products }\end{array}$ & $\begin{array}{l}\text { Seller acknowledges and agrees that } \\
\text { the Tokopedia has the right to do } \\
\text { moderation souvenir Seller if Seller do } \\
\text { rejection, cancellation and/or does not } \\
\text { respond to order Goods belonging to } \\
\text { the buyer with the alleged transaction, } \\
\text { trespass to manipulate the and } \\
\text { conditions, and/or other abuse or } \\
\text { fraud. }\end{array}$ \\
\hline BUKALAPAK & $\begin{array}{l}\text { - Register as a Seller } \\
\text { - Upload Products } \\
\text { - Promote }\end{array}$ & $\begin{array}{l}\text { The following are the sanctions that } \\
\text { would be acceptable to users if } \\
\text { abused accounts or violate the rules } \\
\text { of use of Bukalapak: } \\
\text { - The accounts were frozen. } \\
\text { - Account is disabled. } \\
\text { - Wallet frozen. } \\
\text { Reported to law enforcement } \\
\text { authorities. }\end{array}$ \\
\hline BLI-BLI & $\begin{array}{ll}\text { - } & \text { Register as seller } \\
\text { (upload ID/passport) } \\
\text { - } & \text { Complete store } \\
\text { information } \\
\text { - } \\
\text { Administration } \\
\text { information }\end{array}$ & $\begin{array}{l}\text { Reserves the right to restrict, block or } \\
\text { terminate the service of an account, prohibit } \\
\text { access to the site blibli.com and the content, } \\
\text { services, and slow down or remove hosted } \\
\text { content, cancel the transaction, perform the } \\
\text { freezing, delays and/or cancellation against } \\
\text { withdrawals done and take legal steps to keep } \\
\text { registered users or other users if we consider } \\
\text { registered users or other users violating } \\
\text { applicable laws, violated property rights } \\
\text { intellectuals from related parties, doing fraud } \\
\text { (fraud) or commits an offence matters }\end{array}$ \\
\hline
\end{tabular}


specified in this agreement.

\section{Results and Analysis}

After conducting the research and response from the questionnaire get a sample with a age of 21 majority with a Total of 24 people followed by the age of 20 with a Total of 16 people on age 19 and 22 with 3 people and up to $26-45$ years of age from 53 response questionnaire. 53 responses of $54.7 \%$ were 29 men's gender and $42.5 \%$ were 24 female genders . $90,6 \%$ with 48 people have been shopping on Marketplace and $9.6 \%$ with 5 people have never shopped in a Marketplace. Lazada became the first Marketplace with $64,6 \%$ of 31 people last response to Shopee with $56,3 \%$ of 27 people followed by Tokopedia $43.8 \%$ of 21 people responded then Bukalapak $22.9 \%$ of 11 people then at the incessant bli-bli $8.3 \%$ of 4 People and JDid 2.1 of 1 person total of all 48 total people who responded. From 53 people, $66.7 \%$ of the response was 32 people said it was never deceived and $33.3 \%$ were 16 people responding yes already been deceived by the seller. Shope became the first $50 \%$ order of the 8 people who had been deceived in a Marketplace followed Tokopedia $43 \%$ of 7 people followed by Lazada, Bukalapak and OLX.

There is a difference in the big marketplace. The first difference lies in the requirements to become a salesperson on the big Marketplace as in Lazada. An obligation to have a Tanda resident card proves that it affects the guarantee of a seller. These terms affect that not all ages can be sellers on Lazada. Only those who have a resident card of age below 17 years old are not allowed to sell. With any of his terms have a token of security resident card can easily keep track of the fraud of a seller. Because of the responsibility of the owner of the resident card, that will be processed if there is a violation of the law in the seller.

Unlike Lazada as a marketplace in general there are terms and conditions for sellers to sell more responsibly. This proved to be a punishment or sanction that the seller would feel if not in accordance with the provisions. The Constitution acts on penalties and sanctions on fraud. But not all implement the use of KTP (ID card) to be a seller in a Marketplace. It affects the authenticity of a seller's data.

\section{Conclusion}

Looking at the big marketplace This can be one of the key answers to the problems that exist so we can see the requirements in the marketplace. These requirements become our reference, as to what the requirement is to become a seller in the marketplace if so security is assured. Avoiding any of the deceptive sellers in the marketplace. See also in terms of the constitution for online seller fraud in Indonesia.

With the supported scientific journals from others regarding security, marketplace, Buyer Trust, e-commerce. Be one of the support to see how it becomes one of the workarounds. Seeing how the research is doing this shows that customer trust is the main thing. How also security in the marketplace is highly dependent on buyers. This reduces the fraud that a seller has made on the marketplace.

The requirement to become a seller on Marketplace has a significant impact on security and buyer confidence. It is apparent that with the seller's authenticity, the buyer will trust the marketplace more. This is because if the seller cheats the buyer, it will affect the good image and trust of the buyer. More and more sellers are deceiving the more buyers will not use the marketplace to buy items. That way the marketplace will suffer losses. It is hoped that only the Marketplace is huge but the growing small Marketplace has increased the requirements for sellers to avoid fake identities for sellers who want to cheat.

\section{References}

[1] Yulianto, Fifit Alfiah, Eka Purnama Harahap, Baiq Aneji Pahad, Andriyanto, lan An Azhari, Riyan Sindi Saputra. Analisa Peranan Teknologi Internet Sebagai Media TRANSAKSI ECOMMERCE DALAM MENINGKATKAN PERKEMBANGAN EKONOMI. Seminar Nasional Teknologi Informasi dan Multimedia. 2015. ISSN : 2302-3805.

[2] Sunarya, A., Rahardja, U., \& Wanda, A. KEPUASAN PELANGGAN ROOSTER ATAS KINERJA PELAYANAN ROOSTER PADA PERGURUAN TINGGI RAHARJA. CCIT Journal, 2015 Vol.9 No. 1 ISSN: 1978-8282. 
[3] Qurotul Aini, Untung Rahardja , Anggy Fatillah. Application of QR Code as Media Services for Attendance on the Website Based Php Natively. 2018. Jurnal IImiah SISFOTENIKA. (Vol. 8, No. 1).

[4] Untung Rahardja, Qurotul Aini , Made Bunga Thalia. Application of Yii Framework OnlineBased Payment Confirmation Form at Higher Education. Universitas AMIKOM Yogyakarta. ISSN: 2460-4259.

[5] Yulianto, Alfiah, Fifit., Baiq Aneji Pahad, Eka Purnama Harahap,Wawan Setiawan, Wiwin Sanjaya, Abdul Gopur. Peran Teknologi Open Source Arduino Untuk Melaksanakan Memaksimalkan Kinerja Kebutuhan Manusia Dalam Kehidupan Sehari-Sehari. Seminar Nasional Teknologi Informasi dan Multimedia 2015. STMIK AMIKOM Yogyakarta. ISSN : 23023805 4.3-31.

[6] Untung Rahardja, Po Abas Sunarya, Qurotul Aini, Shylvia Ratna Dewi. Solusi Payment Online Berbasis Cloud Accounting Pada Manajemen Berbasis Perguruan Tinggi. INFOTEKJAR : JURNAL NASIONAL INFORMATIKA DAN TEKNOLOGI JARINGAN- VOL. 3 NO. 2 (2019).

[7] Ahmad Farki, Imam Baihaqi, dan Berto Mulia Wibawa. Pengaruh Online Customer Review dan Rating Terhadap Kepercayaan dan Minat Pembelian pada Online Marketplace di Indonesia.

[8] Desak Made Prilia Darmayanti Ketut Suardita. Kajian Terhadap Tindak Pidana Penipuan Melalui Jual-Beli Online. 2017.

[9] Edwin Hadi Setiawan. Pengaruh Keamanan, Kemudahan, Kepercayaan, dan Resiko Kinerja Terhadap Keputusan Pembelian Secara Online.

[10] Dewa, B. P., \& Setyohadi, B. (2017). Analisis Dampak Faktor Customer Relationship Managementdalam Melihat Tingkat Kepuasan Dan Loyalitas Pada Pelanggan Marketplace Di Indonesia. Telematika, 14(01).

[11] Periamsyah, P., Subhan, S., \& Syahab, A. (2018). Analisis Sistem E-Commerce Pada Perusahaan Marketplace Mobile Shopee Indonesia. SENSITEK, 1(1), 565-569.

[12] Sudaryono, Rahardja, U., \& Eka Purnama Harahap.Implementation Of Information Planning and Strategies Industrial Technology 4.0 to Improve Business Intelligence Performance on Official Site APTISI.Journal of Physics: Conference Series, Volume 1179, conference 1 